\title{
Using Online Recount Texts to Improve the Eighth Graders' Reading Comprehension
}

\author{
$1^{\text {st }}$ Nur Fitria Anggrisia ${ }^{1}, 2^{\text {nd }}$ Maslihatul Bisriyah ${ }^{1}$ \\ \{ria.anggrisia@gmail.com ${ }^{1}$, maslihatulbisriyah@gmail.com\} \\ Universitas Islam Negeri Maulana Malik Ibrahim, Malang ${ }^{1}$
}

\begin{abstract}
This study was intended to apply online recount texts to solve the problems of the eighth graders of SMPN 1 Sukodono in 2013/2014 academic year in reading recount texts. The reading materials were taken from the British Council site. This design consisted of one cycle involving four steps or procedures. They are planning, implementation, observation, and reflection. The finding showed that by using online recount texts, the students could improve their reading comprehension. This was proved by improving the students' score from 68.6 in the preliminary test to 79.7. The numbers of students who passed the passing grade (75) improved from $36.12 \%$ in the preliminary test to $88.88 \%$ after the implementation of the strategy. Their reading skills developed, mainly in identifying main idea and detailed information, and classifying the text structure. Lastly, in terms of the students' attitude or response toward the application of online recount texts, $91 \%$ students gave positive responses.
\end{abstract}

Keywords: online texts, recount text, reading comprehension

\section{Introduction}

Reading is an essential skill in English that should be mastered by the students. As stated on the content standard, the objective of teaching English in the junior high school especially eighth graders, students should master the procedure, descriptive, recount, narrative, and report text types [1]. The eighth grade students in the second semester are expected to be able to do the following reading skills. Firstly, they are expected to be able to read aloud a functional, short and very simple descriptive and recount text with good pronunciation, stress, and intonation. Secondly, the students are expected to be able to respond to the meaning in functional short texts accurately, fluently, and appropriately. Thirdly, they are expected to be able to respond to meaning and rhetorical structures in short, simple descriptive and recount texts accurately, fluently, and appropriately [1].

In this digital era, students continuously have an access to new information and this forces them to move from "learning to read" to "reading to learn". Reading to learn means student's purpose of reading is to get information. Students then have to integrate the new things into their knowledge, build new understanding, and adapt existing conceptions, belief and theories. Hence, the researchers considered eighth graders as the subject of this study since the researchers claim that they have enough background knowledge. Students who have less background knowledge may struggle to gain access, to join and to advance throughout the curriculum, in which reading to learn is a must in order to gain success. Besides, as stated on 
the syllabus, one objective of teaching English in the junior high school especially eighth graders, students should master recount texts.

Based on the unstructured interview with the English teacher and some of the students of 8D class of SMPN 1 Sukodono, it was revealed that the students' ability in reading was poor. The result of a preliminary study conducted by the researchers at school found some students' problems in reading skill, namely: the students got difficulties in understanding the texts and also had low mastery of vocabulary. Besides, the students were less enthusiastic in learning English reading. Most students disliked reading skill, it was because they thought that reading English texts was difficult and they could not understand the content. Meanwhile, from the teacher's side, students claimed that most activities in learning reading English were dominated by the teacher. In the preliminary study, some students were also assigned to do a reading test. Their reading test score on average indicated that it was below the minimum passing level (Kriteria Kentutasan Minimal) that is 68 from 75. The number of students who passed this level was 13 out of 36 students who took the test. From the description above, it can be assumed that the students' difficulty in understanding a text aroused from interrelationship between the effort of remembering a lot of vocabulary which frustrates the students and the teacher-centered instruction.

Therefore, as teachers, we must convince the learners that reading is interesting, for instance by giving them fun reading materials so that they will not get bored or we can make some fun activities. As [2] states, reading is an enjoyable and private activity. Reading is not only to give the students information but also it also need to give pleasure toward the students. Providing an interactive and productive reading class is one of the teachers' tasks. Teacher might have to take it into account that not every students have ability to understand reading texts.

Referring to the above information, it showed that students of $8 \mathrm{D}$ have low ability in reading skill especially in terms of understanding the text. Therefore, it gives an overview for the researchers to do an action research in this class. This is meant to bring about the changes for the improvement in English teaching and learning process. For that reason, there is a need to implement another teaching strategy that will bring the improvement. The researchers, thus, proposed to utilize one of the effective strategies in teaching reading by using extensive reading with the integration of technology. Here the researchers used online recount texts as the proposed solutions. Students need to read as much as possible and the teachers need to provide texts that interest students and are at students' level of difficulty. Hence, extensive reading can help building students' vocabulary [3]. Moreover, this method also aims at increasing students' fluency and speed in reading.

The availability of electronic devices and the internet within our society may contribute to declining students' time for reading. Prensky said that today's generation can be referred as digital natives [4]. Digital Natives are those who are born in the nowadays era in which that their brains are automatically into electronic devices, such as computers, smartphone, and the internet. Researchers claim that this generation needs to be more electronically engaged activities. Indeed, children and teenagers today are more attracted to electronic devices than any other type of entertainment [4], [5], [6].

In order to fulfill the needs of students' literacy development, researchers and educational authorities claim that traditional teaching styles should be modified [4], [5], [6]. They also claim that technologically engaged class will provide the educator with relevant and more efficient education towards their students.[7]. Such technologies include PowerPoint presentations, online communication systems, online discussion boards, online reading materials and multimedia teaching techniques within the classroom [5]. 
Online recount texts are one of internet resources offered related to reading materials. These resources consist of any kind of short stories, which can be explored and read online, or offline. These features process new characteristics which differentiate from the printed ones. They belong to, first, non-linear hypertext because there is a combination of images and sounds, and second, multimedia text which many hyperlinks embedded with short passages [8]. Dealing with the new characteristic possessed by web-based material, readers are required to possess 'new literacy skill in order to process the text. This skill deals with electronic literacy which involves readers' ability to navigate for information and critically interact with the online text in the web.

The consideration for choosing Online recount texts for teaching reading was based on several reasons. The students could learn English through various kinds of reading materials that are taken from the internet. Pictures, animations, or videos help readers catch the meaning of sentences that appear by pages. Oral reading helps the students maintain their pronunciation. Reading exercises and games in the form of vocabulary and comprehension quizzes facilitate the students to understand the content of the text. By using internet as a media, it can help the teacher to solve the problems of access and expense. Teachers are possible to find other sites which provide various materials that are downloadable and print them out for students' use, if the school has limited facilities for internet access. Besides, many advantages can be obtained obtained from web-based materials in teaching reading for the students. As stated in [9], a class which use a highly advanced technology will enhance both students and teachers. The students will also be more active, well-motivated and more involved in language learning process in the class. By using internet as media, it can motivate the pupils and engage them in the speaking, writing, reading and listening skill. Moreover, Web-based activities can encourage weak learners to interact with the teacher without inhibition. The teacher can find out each student's weaknesses and thus provide her or his advice, guidance and support in terms of learning. Along with multimedia progressing in education, web-based extensive reading program helps students learn vocabulary, read for main ideas, and increase speed and fluency in reading a text.

Online recount texts in teaching reading is a significant strategy since it provides an alternative for the schools that have high accessibility on the internet but has limitation on providing students reading materials. The researchers choose this strategy because the appearances are more interesting. Students can use this strategy by online during the class or offline by downloading the materials before. There are many websites which provide short stories as materials, but here, the researchers focus only one website that is British Council Learn English kids.

Online recount texts as an alternative material for teaching reading, the researchers focus on teaching recount texts. Through recount texts, students are expected to be able to learn language easily. They were encouraged to understand the story chronologically [10]. Students will also encourage their comprehension on explicit and implicit elements of the story, and generic structure used by the author in the text. Besides, based on the objective of teaching English in the junior high school, recount text and descriptive text are one of the genre texts which the students should master.

A study entitled 'ICT and Reading: In the Technology-Enhanced Extensive Reading Classroom' found that ICT, especially computer or internet has major benefits on students' achievement in reading [9]. These technologies motivate students to read both intensively and extensively, strengthen their reading competence and make them enjoy the reading process.

Concerning with the problems in reading ability, the researchers conducted a research entitled 'Using Online recount texts to Improve Eight Graders' Reading Comprehension in 
SMP N 1 Sukodono". The researchers believe that online recount texts equipped with valuable features can benefit teaching reading on recount text especially as a medium and materials. The study, then, was conducted in this school because it has internet access. The eighth graders students were chosen as subjects of this research under consideration they have been familiar with internet browsing. Recount texts are presented in Standar Kompetensi of eighth graders of SMP/MTS as being mentioned also in Standar Kompetensi Lulusan. Thus, learning can be delivered through online recount texts that cover the material.

\section{Methods}

The study used a method of classroom action research. The classroom comprised of eighth graders students of SMPN 1 Sukodono. This cycle was implemented in five meetings and conducted on May $12^{\text {th }}$ to June $9^{\text {th }} 2014$.

\subsection{Design of the Study}

The design of this study is a classroom action research (CAR) that focused on a particular group of students. It is collaborative research where in conducting the research, the researchers were backed up by one of their colleagues at school [11].

The researchers as the practitioners handled the teaching process of reading comprehension through the strategy to the students of the class being investigated while the teacher as the collaborator observed and recorded all the data found during the implementation. In this case, the researchers worked together with her collaborator who was involved from the beginning up to the end of the process of the research activities. Besides, in adjusting the strategy the researchers targeted to obtain the way out of the classroom strategy problems in teaching reading.

Before conducting the research, a preliminary study was done to identify students' problems before implementing the plan. It aims at finding out the students' cases in reading comprehension. Furthermore, this activity was done in order to design the appropriate planning to solve the problems.

This study employed a Classroom Action research model developed by Kemmis and Mc Taggart which covered four steps, namely: planning, implementing, observing and reflecting. In this research, collaboration and cooperation are needed in terms of providing a powerful medium of reflection. In conducting collaborative classroom action research, the researchers needed a teacher as a collaborator. The researchers made collaboration with one of the English teacher of SMPN1 Sukodono. The researchers took their role as teacher-practitioners who applied the strategy proposed. The collaborator acted as an observer who assists in handling the research from the beginning to the end. It included the procedures of the strategy, the impact on the students' learning, and examined the students' performance.

In line with the action research procedure, in the planning stage, some preparations were made, including preparing teaching strategy, designing a lesson plan, and setting the criteria of success. In implementing stage, the teacher implemented the strategy to the students in the teaching and learning process while the observation stage is dealing with the data collection. In the last stage, the reflection stage refers to data analysis.

\subsection{Setting and Subjects of the Study}


The research was conducted at SMP N 1 Sukodono Sidoarjo. The school had twentyseven rooms for classroom teaching learning activity, supported by one language laboratory, one computer laboratory, and one library. The research was conducted at the eighth graders of SMP N 1 Sukodono at the second semester in the 2013/2014 academic year. The class consisted of 36 pupils. This subject was chosen because their reading comprehension skill in this school was quite low.

\subsection{Procedures of the Research}

This research started with the general idea of how students' reading comprehension could be well improved by the used of Online recount texts strategy. Then, it is implemented and observed. The reflection was carried out to identify all facts including success and failure. The procedures of the actions were adapted from Kemmis and Mc Taggart which consists of four steps as follow: (1) planning, (2) implementing, (3) observing and (4) reflecting.

The strategy that was employed in this study is online recount texts. The role of Online recount texts as a strategy was under the reason that this strategy can be any kind of tools or ways that the teacher uses to help learners learn [12]. Online recount texts were ready used materials for reading comprehension that were taken from the internet. British Council site is the site that was chosen for this study. The researchers took all the reading materials from this website. This website presents many recount texts; imaginative recount and personal recount in numerous topics. This website appropriates reading materials since the themes are interesting and attractive for teenagers. The stories are in the form of animation and video which is supported with printable materials for each story. Sentences which appear in every page are combined with images illustrating the meaning and sounds showing how to read and pronounce the words correctly. Besides, there are some features of reading comprehension exercise, list of vocabulary, and puzzle for each text. These features provide students some instrument for self-improvement on their reading skill. Furthermore, these media and materials cover the diversity of students' learning styles, and meet the provision of constructivism where the students are allowed to maintain their roles to construct their knowledge by interacting with their environment; computer, worksheet and teachers and friends [12].

To make the students able to learn effectively, a well-designed lesson plan was set up as teacher's guideline to implement the strategy. This included the standard competence, learning objectives, instructional media and materials, teaching and learning activities and assessment.

It is linear with the basic competence stated in the content standard of Junior High School. The instructional objective of the eighth graders was to respond to meaning and rhetorical structures in short, simple recount and descriptive texts accurately, fluently, and appropriately related to the students' close environment [1].

The instructional media and materials were online recount texts. Since using online recount texts was the strategy of this research, the reading activities were mostly facilitated by the use of computer and internet as media. Here, the internet was used as a main medium and material source. The material was focused on recount text for its appropriateness to eight grade level as being stated in syllabus. Some tasks were arranged by adapting some exercises that followed the online stories in order to maintain the students' attention and help their comprehension. 
The teaching and learning activities were divided into three phases, Pre-reading, Whilstreading and Post-reading. These three phases were chosen in the regard of the needs to build students' base knowledge, present a modeling and facilitate students in group work to individual work. Pre-reading stage was maintained to prepare the students readiness, such as open their knowledge related to the materials. Whilst-reading was focused on the reading with the worksheets that have been prepared. And Post-reading provides time for rechecking comprehension and doing reflection for learning process.

The assessment was constructed in order to know the students' improvement. Referring to learning objectives and the activities, the researchers set on-going assessment both for group and individual. The researchers used worksheets completed with scoring rubric through which the researchers could analyze the score as the evidence of their progress. However, the students' achievement cannot be seen only after the first meeting has been implemented. Referring to [13], suggests that the teacher as researchers must bring students to be familiar with the strategy first, so that students' progress will possibly appear after two meetings, the researchers modified the activities in every meeting in the lesson plan as well as the format of worksheets.

In this study, the researchers prepared the rooms that would be used as well as the internet access. Here the researchers used science laboratory because this room can reach the internet connection to open the website. Besides, to avoid students' distraction, the researchers prepared a written guide which consisted of the web addresses from which the materials were taken, the steps of browsing so that the students could find out online materials properly. This way is thought to be effective for teacher's instruction since most students like to ask directly when they got difficulties.

The criteria of success were established to confirm whether the implementation of the strategy had influenced the students in improving their reading comprehension ability. The decision for the criteria of success was determined based on the improvement on both of the students' scores, their active participation in the learning process, and their responses towards the strategy. The result of the reading test in the preliminary study showed that students average score was 68 which indicated that they did not pass the minimum passing level that is 75. However, if $80 \%$ of the students gained an average score 75 after the implementation of the strategy, or the scores after the action gained 7 points higher than their score in the task before, it could be claimed the action was successful to improve the quality of their ability in reading texts. However, if it does not achieve it, the action must be continued.

The achievement reading test was used to measure the students' achievements in understanding the recount texts by using online recount texts. They were 25 items of multiple choices and had to be finished in 60 minutes. The test items were constructed based on analyzing the content of the test and the materials required in the English syllabus of the second year of the junior high school. The purpose of analyzing is whether the content of the test represents the basic competence of reading for eighth graders of junior school in English syllabus.

\section{Results and Discussion}

The discoveries of this study indicated that the use of online reading materials in reading comprehension teaching and learning could solve the problem they are facing in reading, as the previous studies indicated [12], [14]. As identified in preliminary study, the students had 
problem in reading in terms of difficulty to understand the texts and the students had low mastery of vocabulary. The discoveries of the strategy effectuation were broken down from the four research instruments used, observation checklists, field notes, reading comprehension test and questionnaire. The learning and teaching process qualitative data regarding the interaction between teacher and students were ensued from the observation checklists and field notes. Those were then confirmed with the analysis on the questionnaire. The students achievement qualitative data were obtained from the grade they got both in daily exercise and the reading comprehension exercise.

The effectuation of using online recount texts strategy to help students of SMPN 1 Sukodono, especially the $8^{\text {th }}$ grader to enhance reading ability in this research was conducted in one cycle because the result of this one cycle indicates that they have succeeded. This cycle was effectuated in five meetings and conducted on May $12^{\text {th }}$ to June $9^{\text {th }} 2014$. The time allocation of each meeting was $2 \times 45$ minutes. The first meeting to the fourth meeting was used to implement online recount texts and its application, while the fifth meeting was used to administer the reading test.

The topic of recount texts in each meeting was different. The recount text in the first meeting was about 'My Secret team'; the second meeting was about 'No Dogs'; the third was about 'The lucky Envelope' and the fourth meeting was about 'A Dogs Life'. In the fifth meeting, the researchers reviewed all the topics and gave the students exercise. Each topic of the text was presented in the form of online texts and printed materials downloaded by the researchers before class for students' worksheet.

\subsection{The Result of Reading Test}

To evaluate the students' participation during the teaching-learning process, the researchers used an observation checklist, field note, and questionnaire. The reading test taken in the form of multiple choices consisted of 25 questions items. All the questions were based on the reading texts that they had learned before. The number of students who became the subjects of this research was 36 students.

The students' reading test was administered at the fifth meeting of the cycle. The test was intended to know the implementation of the strategy applied, to know how well the students' reading ability was, and to evaluate the students' reading comprehension. The implementation of online recount texts in the learning process was accompanied by some worksheets that provided scaffolding questions for comprehension. The worksheets used during the four meetings contained story map and reading comprehension exercise based on the text adapted given in each meeting.

In addition, there was also an improvement in students' scores. There were 32 students $(88.88 \%)$ who achieved scores in the good category $(\geq 75)$ and 4 students $(11.12 \%)$ who achieved score in the "poor" category $(<75)$ compared to the preliminary study showing that there were 13 students $(36.12 \%)$ who got scores in good category $(\geq 75)$ and 23 students $(63.89 \%)$ who got scores classified as "poor" category $(<75)$. It can be concluded that most of the students got higher scores in cycle 1 than the previous score that they obtained in the preliminary study.

\subsection{The Students' Involvement in the Teaching and Learning Process}

The collaborator completed the data of the students' involvement during the implementation of this strategy in this meeting during the teaching and learning process based on the specific guide written down in the observation checklist. 
From the data presented in the observation checklist, it was found that in the first meeting, 19 to 30 students were involved and performed good activity in the teaching and learning process such as paying attention to the teacher's explanation and used online dictionary in another page to find the meaning when they could not guess the meaning of difficult words. Because this strategy was new for the students so in the first meeting most of the students asked for help when they got some difficulties in browsing and asked for explanation on the worksheet. There were 10 up to 18 students who gave comments or responses to the teacher's instructions and questions and had great willingness to work on the worksheets both in group and individually. But, only some students could finish their work quickly before time was up. It occurred because most of the students were still confused about their worksheet. The percentage of the students' involvement was $75 \%$.

In the second meeting, the students participated very well in showing their enthusiasm and interest in the teaching and learning process and paying attention to the teacher's explanation while 21 to 30 students did good activities such as responding to the teacher's instructions, doing the exercise in group and answering the teacher's questions. The percentage of the student's involvement was $78.5 \%$. Then, In the third meeting, 31-36 students were very good in paying attention to the teacher's explanation, understanding the teacher's explanation, responding to the teacher's instruction, feeling comfortable and enjoyable in attending the class and showing enthusiasm and interest in the teaching and learning process, while 19 to 27 students performed in good condition like asking the teacher if the students did not understand, got difficulties in browsing, understand the teacher's instruction, answering to the teacher's questions and working in individual or group to solve the problem. The quantity of students who were able to finish their work quickly before the time was up was greater than previous meetings. The percentage of students' involvement is $82.1 \%$.

In the fourth meeting, most the students were very good in paying attention to the teacher's explanation, answering the teacher's instructions and questions, having great willingness to finish their worksheet either in individual or group and also most of them finished their work before the time was up, while there were 19 up to 27 students asked for help when they did not understand about their worksheet, got difficulties when browsing and opening the online dictionary to find the difficult words in the text. The percentage of students' involvement in this fourth meeting is $89.2 \%$.

From the result of observation sheets, it can be concluded that the condition and situation in the teaching and learning process in reading class by using Online recount texts was good and students always got improvement from the previous meeting to the next meeting. It could be seen in the percentages of the first meeting which was $75 \%$ to $78.5 \%$ in the second meeting, $82.1 \%$ in the third meeting and $89.5 \%$ in the fourth meeting. The average of the students' participation in the teaching and learning process obtained from observation checklist was $81.3 \%$. The percentage was obtained from the result of percentage in four meetings divided into four. That number met one of the criteria of success set in this research.

\subsection{Reflection}

The presented data above concludes that researchers could attain the standard of success in the progress, the product, and the students' responses. As in the previous subchapters, the students' involvement score during the use of online recount texts in Class 8D was more than $80 \%$; it was $81.3 \%$. In addition, there were more than $80 \%$ of the students who passed. There had been $88.88 \%$ students who had score above 75 (see Appendix 9). Similarly, the percentage of the students who response positively toward the whole activities in the process- 
genre approach was also more than $80 \%$; there had been $91 \%$ students. All in all, Cycle 1 concludes that the researchers could fulfill the success standard; hence they did not have to go for another cycle.

\section{Conclusion}

The discoveries of this study conclude that the use of online recount texts in teaching and learning reading could solve the eighth grader's students' problem in reading ability. This can be concluded by seeing that the students improved in three aspects. Those three aspects includes how active the student is participating in class activity, the students' reading test, and how many students who respond positively toward the application of online recount texts.

The use of online recount texts in teaching and learning reading process used three stages of activity (pre-reading activities- whilst reading activities- post-reading activities) method and the stages in using this method were (1) explaining the topic and showing how to browse the texts through the internet, (2) delivering the texts and giving worksheets based on the texts in every meeting then discussing the result, and (3) giving pre-reading test as the exercise in the last meeting before giving the final reading test.

The process of implementing online recount texts helped the teacher and the students in the teaching and learning of reading class. This was proved by the results of the observation checklist, field note, questionnaire and 32 of 36 students $(88.88 \%)$ successfully passed the final reading test.

Finally, the finding showed that the implementation of online recount texts had successfully improved the students' ability in reading text especially recount. This online recount texts also made them work with enthusiasm; they also had new possibilities to access knowledge in a different way to improve their reading comprehension.

Acknowledgements. This paper in conjuction with The $3 \mathrm{rd}$ International Conference on Islamic Education, Information Technology and Media: Challenges and Opportunities (ICIED) in Malang, East Java.

\section{References}

[1] Depdiknas, Peraturan Menteri Pendidikan Nasional Republik Indonesia Nomor 22 Tahun 2013 Tentang Standar Isi Untuk Satuan Pendidikan Dasar dan Menengah, Jakarta: Departemen Pendidikan Nasional, 2013.

[2] J. C. Alderson, Reading in a Foreign Language, London: Longman, 2002.

[3] B. Blair, Reading beyond the textbook: Why is extensive reading important?, 2012.

[4] M. Prensky, Listen to the natives, Educational Leadership, 63(4), 8-1, 2006.

[5] C. K. Kinzer, The importance of recognizing the expanding boundaries of literacy, Reading Online, 6(10), 2003.

[6] S. Wright, A. Fugett, and F. Caputa, Using E-readers and Internet Resources to Support Comprehension, Educational Technology \& Society, 16 (1), 367-379, 2013.

[7] S. Bennett, K. Maton, and L. Kervin, The 'digital natives' debate: A critical review of the evidence, British Journal of Educational Technology, 39(5), 775-786, 2008. 
[8] J. Coiro, Reading Comprehension on the Internet: Expanding our understanding of reading comprehension to encompass new literacies, The Reading Teacher, 56, 458-464.2003.

[9] B. Assia, ICT and Reading: In the Technology-Enhanced Extensive Reading Classroom, The Case of 1st Year EFL Students at Hassiba Ben-Bouali, 2012.

[10] G. Anderson, Fundamental of Educational Research, London: Falmer Press, 1998.

[11] M. A. Latief, Tanya Jawab Metode Penelitian Pembelajaran Bahasa, Malang: UM Press, 2010 .

[12] I. Indriati, Using Online Short Stories to Improve the Reading Comprehension Ability of the Eighth Graders of MTsN-2 Palangka Raya, Thesis, Graduate Program in English Language Teaching, State University of Malang, 2011.

[13] H. D. Brown, Language Assessment: Principles and Classroom Practices, New York: Pearson Education, 2004.

[14] Y. N. S. Rahayu, Using Computer Based British Council's Short Stories To Improve Reading Comprehension For The Eighth Graders of MTs Hamid Rusydi Malang, Unpublished thesis Graduate Program in English Language Teaching, State University of Malang, 2011. 